Original article

\title{
EGYPT AS A REWARD FOR THE KING IN PTOLEMAIC TEXTS
}

\author{
Sayed, M. \\ Archaeology dept., Minia Univ., Minia, Egypt \\ E-mail:mohragab82@gmail.com
}

\begin{abstract}
Kings and gods adorn the walls of Egyptian temples in face-to-face meetings. The relation between the King and the gods in offerings scenes represents the idea of an exchange or describes the exchanges between the King and the gods. The benefit of the offerings represents both the act of the King and the reward of the gods to him. When the King (provider) gives an offering to the gods (recipients) they give to him a good reward related with that offering. The subject of this paper is a special kind of reward. In some offerings the King is rewarded with Egypt itself, Kmt and its synonyms (Isty, B3kt, $S n w t, T 3, T 3 w y, T 3-m r y, T 3-\check{S} m^{\ulcorner} w, T 3-M h w$ ). The paper will discuss the hieroglyphic words for the word "reward" and its synonyms. And it will examine a number of texts where Egypt appears as a reward for the King.
\end{abstract}

Keywords: Egypt, Kmt, Offerings, Reward, Grant, Gift, King

\section{Introduction}

The meeting of king and gods represent the most important scenes on temples. The king always keeps offerings being present to gods. The offering, is a code that has remained the same from one period to another: the perpetual exchange between king and god is taking place amongst the offerings of bread and flowers, in the midst of uninterrupted celebration [1]. When the king gives the gods an offering he receives a reward in exchange. The subject of reciprocal offerings to the king is various. For examples: eternal rule, control of enemies, virility, and flood inundation. The most important reward for the king was Egypt itself. This specific reward will follow through documents. The encounter with Egypt is both simple and immediate: the Nile is ubiquitous; we easily imagine the processions that follow it, the journey of the divine boat, purifications, and exultation in the coming of the flood. Several annual crops ensure the prosperity of this "Black land", called Kmt [1]. Egypt has a lot of names in hieroglyphs texts. The most popular name used to refer to Egypt is $\mathrm{Kmt}$. this name was discussed by some scholars to identify its meaning [2]. Egypt represents one rib of a triangle with the king and gods. It is also was the core of the relationship of king and gods.

\section{The word of "reward"}

The Ptolemaic texts are rich with synonyms for the word "reward" such as:

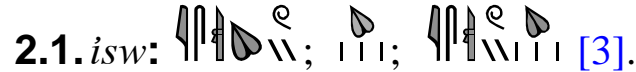

This is the most common word used for "reward", special in texts of friezes to give the idea of exchange payment for what the King has built. The King has built the temple for the god, who gives him in exchange the Kingship in Egypt. 


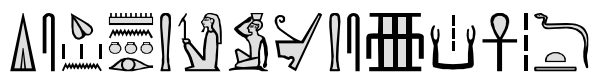 \\ di.s isw n mnw ir hm.f $n$ hmt.s hnty $k 3 w^{`} n h w d t$.}

"She gives a reward for the monu-ment that his majesty (King) made for her majesty

(Hathor) foremost of the living kas eternally" [4].

eI '

Di.w n.f isw n r-"wy.fy $m$ hdt mnht $m$ htp, ir.sn s3.f, whm.sn mkt.f, dr.sn hftyw $n$ hm.f,

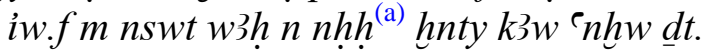

"They give to him a reward for his handiwork consisting of the excellent white crown in peace. They make his protection, they repeat his protection, and they drive away the foes of his majesty, for he is the King of Upper Egypt, who endures for eternity, foremost of the living kas eternally" [5].

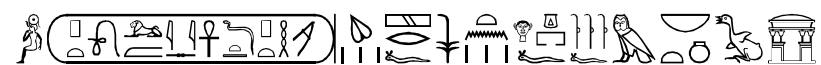

S3-R` ( Ptwlmys, ' $n h \underline{h} \underline{d} t$, mry Pth )| isw hr.fnsyw.f hrr nst.f, rnpwt.f m nb thnt $3 t$.

"Son of Re (Ptolemy, living forever, beloved of Ptah)| a reward for him his Kingship upon his throne, his years as a lord of throne" [6].

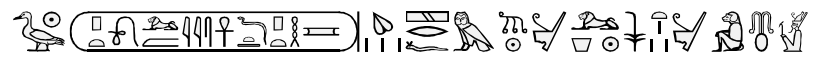

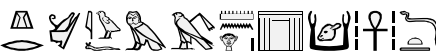

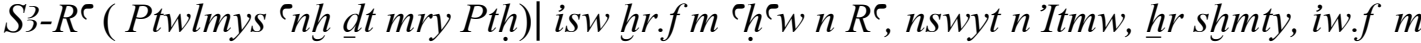
bik mn hr srh hnty $k 3$ w ${ }^{\top} n h w d t$.

"Son of Re (Ptolemy, living forever, Beloved of Ptah)| a reward for him with lifetime of Re, Kingship of Atum, and bearing the double crown. He is the falcon firm upon the serekh (i.e. the throne), foremost of the living Kas eternally" [7].

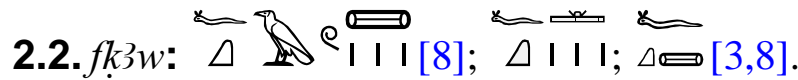

Both verb and noun are used from of a god/goddess for his/her heir. Like the MK literary texts to gives the meaning of gift or reward. The King is given Horus Behdety in Edfou and Hathor in $f k 3 w$ for building the temple as a reward

Dendara.

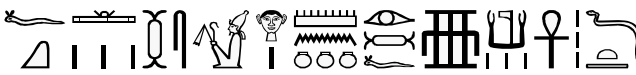

Fk3w.n.s nswt hr mnw ir.n.f hnty k3w $n h$ hw $\underline{d}$ t.

"She has rewarded (Hathor) King of Lower Egypt for monument that he has made, foremost of the living Kas eternally" [9].

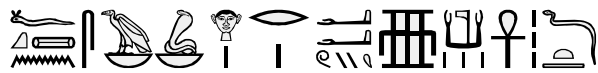

Fk3.n.s Nbty hr r-e`wy.fy hnty $k 3 w{ }^{\top}{ }^{\top} n h w d t$.

"She has rewarded (Hathor) the One of the Two Ladies (King) for his handiwork, foremost of the living Kas eternally" [4].

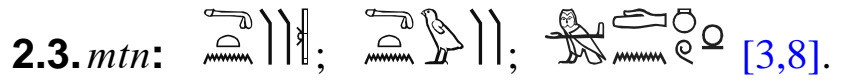

The word $m t n$ can mean either to reward officially confirmed by a written reward or to inscribe and both words receipt or document [3]. may be from the same root. Because the

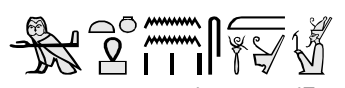

Mtn.n.n sw m i3wt n'Itmw.

"We reward him with the office of Atum" [6]. 


$$
\text { Mtn.f sw } m-3 w \underline{\underline{d} t} \text {. }
$$

He rewards him with the length of eternity. [6]

2.4. $h n: \overleftrightarrow{M}$;

The word means in general "prov- King $\underline{h} n$ here seems to have the more isions" but when associated with the specific nuance "reward" [3].

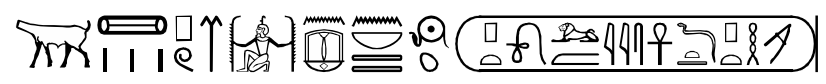

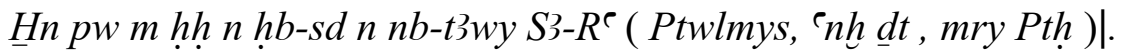

"It is a reward of a million Heb-sed festivals for lord of the two lands son of $\mathrm{Re}$ (Ptolemy, living forever, beloved of Ptah)|" [10].

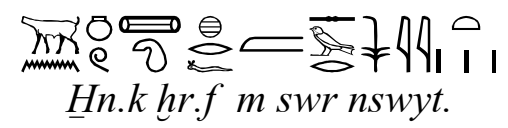

"Your reward is before him; making great (spreads) the Kingship". [6]

2.5. $\left.s ? h: p_{8}\right]_{[3,8]}$

The word is connected with the emaic texts to refer to material posseofficer or rank marker, and used in Ptol- ssions [3].

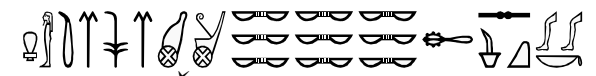

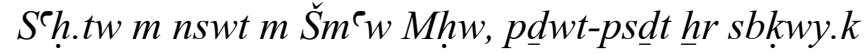

"You are rewarded as a King of Upper and Lower Egypt; the Nine Bows are under your feet" [11].

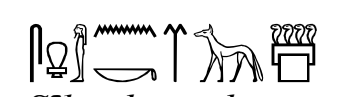

S`h n.km sub-tisty.

"(Thoth) rewards you as the vizier". [12]

2.6. $d w n: ح$

The original meaning of the verb is "to stretch out" $[3,8]$. The verb can be semantically extended to mean "to reward" $[3,5]$.

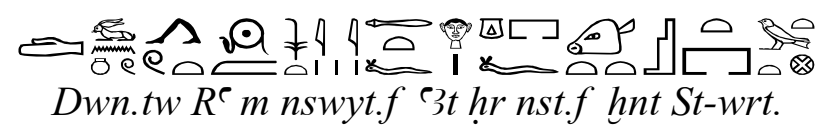

"Re rewards you with his great kingship upon his throne inside the Great Place" [5].

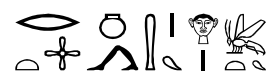

$$
\begin{aligned}
& r \text { dwn hm.f hr k3t.f }
\end{aligned}
$$

"To reward his majesty for his work" [6].

\section{Documents}

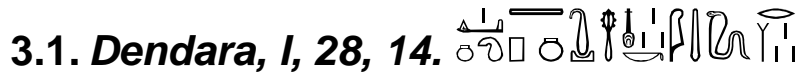

Di.i n.k t3 pn mn(.tw) hr nfrw.k, m3e-hrw.k r sbyw.

"I give to you this land (Egypt) established carrying your good things (offerings); and

3.2. Dendara, I, 97, 9. $\frac{1}{005} \times$ you triumph against

Di.i n.kt3wy dw3 n.k, ḩsswt nbw hr thbty.k

"I give to you the two lands (Egypt) praising for you, all the foreign lands are under your sandals". 


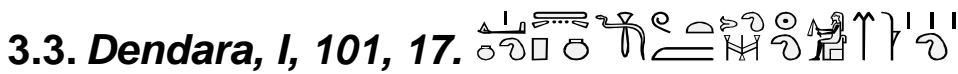

Di.i n.k t3 pn w3 d.tw $m$ rk.k špss $m$ rnpwt.k

"I give to you this land (Egypt) prosperous in your time, enriched of your years".

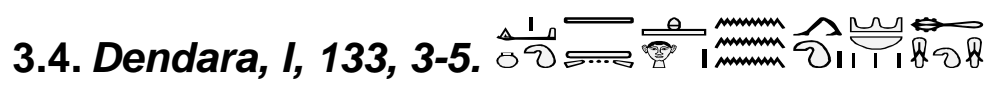

Di.i n.k t3wy htp hr mw.k, ḩ3swt nbw hr tbty.k

"I give to you the two lands (Egypt) content and loyal to you, all the foreign lands are under your sandals".

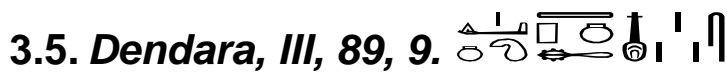

Di.i n.k t3 pn hr nfrw.s

"I give to you this land (i.e. Egypt) carrying her good things (offerings)".

3.6. Dendara, VI, 116, 7-8.

Di.i n.k t3wy hr inw.sn

"I give to you the two lands (i.e. Egypt) carrying their tributes".

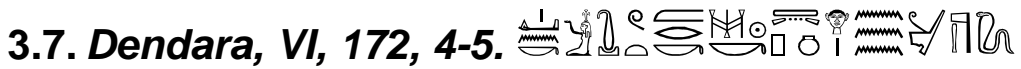

Di.i n.k mrt mn.tw $m$ rk.k, ts pn hr mw $n$ hm.k

"I give to you meret (i.e. maat) established in your time, this land (Egypt) is loyal to your majesty".

3.8. Dendara, VI, 173, 3.

Di.i n.k Kmt b3k.tw n k3.k, shr.i Nb $\underline{d}$ r B3kt

"I give to you Egypt luminous for your Ka, and I drive away Seth from Egypt (i.e. the luminous)".

3.9. Dendara, XII, 4, 2-3.

Di.i n.t Kmt htp hr mw.k ${ }^{(\mathrm{b})}$

I give to you Egypt content and loyal to you.

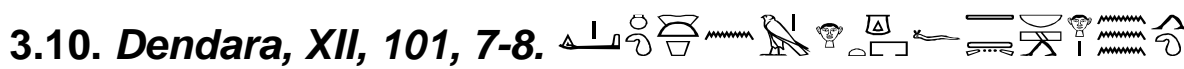

Di.i n.k h̆ n Hr hr nst.f, t3wy nb(w) šm hr mw.k

"I give to you appearance of Horus upon his throne, and all of the two lands (Egypt) are loyal to you".

3.11. Dendara, XII, 102, 14-15.

Di.in n.k Snwt snd $n$ sndt.k imyw.sn $n b(w) m$ w3h-tp

"I give to you Egypt frightened of your fear, those whom in it with bowed heads".

3.12. Dendara, XII, 212, 7-8.

Di.i. n.k t3 pn hr imy.f wrw n.s hr $n$ b3w.k

"I give to you this land (Egypt) carrying what in it, and elders of it having fallen at your might".

3.13. Dendara, XII, 215, 4-5. Di.i n.k B3kt b3k.tw hr nfrw.s t3 $n b m n d y t ~ n h m . k$

"I give to you Egypt luminous and carrying her good things (offerings), every land (being) the serfs of your majesty".

3.14. Dendara, XIII, 14, 13.

Di.i n.k Kmt Dšrt hr r iht.sn

"I give to you the Black Land (i.e. Egypt) and the Red Land (i.e. desert) carrying their offerings". 
3.15. Dendara, $X I V, 180,1-2$.

Kmt hr mw $n$ hm.k

"Egypt is loyal to your majesty".

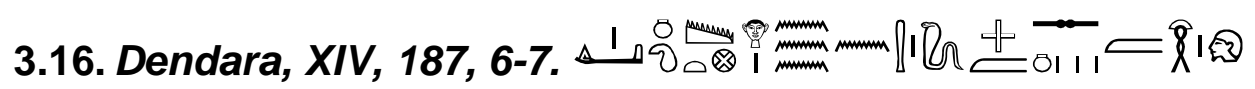

Di.i n.k Kmt hr mw n hm.k imyw.sn $m$ w3h-tp

"I give to you Egypt loyal to your majesty, those who are in it with bowed heads (doing obeisance)".

3.17. Dendara, $X V, 4,14-15$.

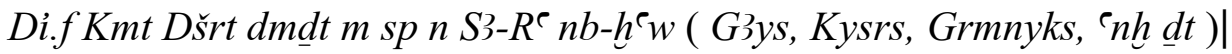

"He gives the Black Land (i.e. Egypt) and the Red Land (i.e. desert) united for Son of Re lord of the crowns (Gaius, Caesar, Germanicus, living for ever)|".

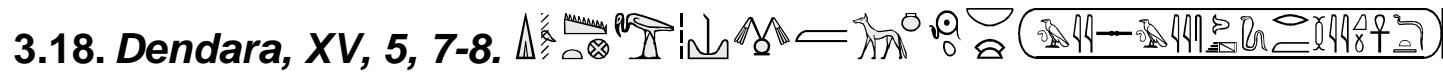

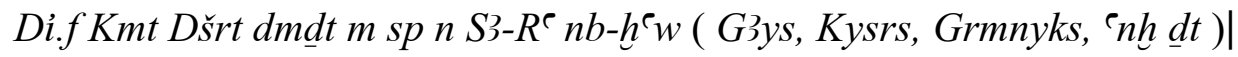

"He gives the Black Land (i.e. Egypt) and the Red Land (i.e. desert) united for Son of Re lord of the crowns (Gaius, Caesar, Germanicus, living for ever)|".

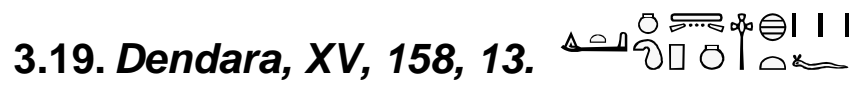
Di.i. $n . k$ ts pn $\underline{h}$ r iht.f

"I give to you this land (i.e. Egypt) carrying its offering".

3.20. Dendara, $X V, 171,8$. Di.i n.k Kmt hr mw $n$ hm.k

I give to you Egypt loyal to your majesty.

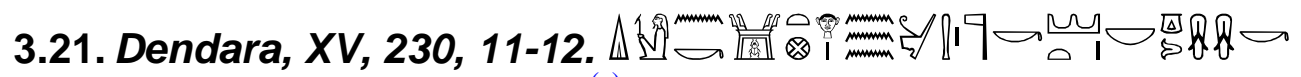
Di.i $n . k$ T3-mry ${ }^{(\mathrm{c})} h r m w n h m . k$, hisst $n b t \underline{h} r \underline{t} b t y . k$

"I give to you Egypt loyal to your majesty and every foreign land is under your sandals".

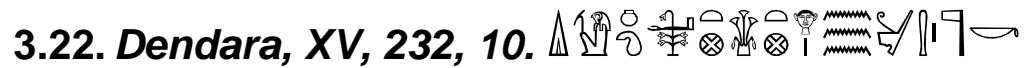
Di.i n.k Šm ${ }^{\ulcorner}$Mhw hr mw $n$ hm.k

"I give to you Upper and Lower Egypt are loyal to your majesty".

3.23. Cauville, S., La Porte d'Isis, 10, 9-10. Di.ì n.k hryt-tp h̆.tw $m$ ḩ3t.k, T3wy nb(w) šm hr mw.k

"I give to you uraeus it shining at your brow, and all the two lands being loyal to you".

3.24. Cauville, S., La Porte d'Isis, 11, 9-10. Di.i n.k T3 pn hr hbi inw m stp-s3

"I give to you this land (i.e. Egypt) gathering tributes in the palace".

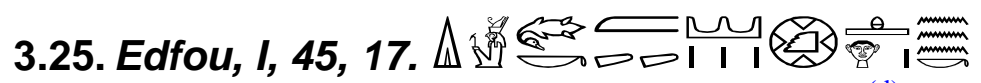
Di.i snd.k $m$ t3wy, ḩ3swt, Kmt $t^{(\mathrm{d})} h t p h r m w . k$

"I place fear of you in the two lands and foreign lands; Egypt is content and loyal to you".

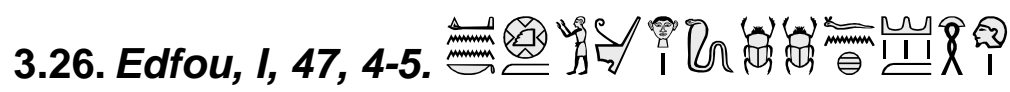

Di.n (.i) n.k Kmt m i3w n hr.k, t3wy-Fnhw m w3h-tp.

"I give to you Egypt praising before your face, and the two lands of Phoenicians with bowed head (obeisance)". 


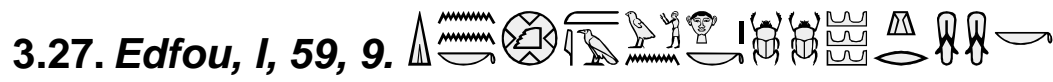

Di.n (.i) n.k Kmt m ijw n hr.k, t3wy ḩ $3 s w t \underline{h} r \underline{t b t y . k}$.

"I give to you Egypt praising before your face, the two lands and foreign lands are under your sandals".

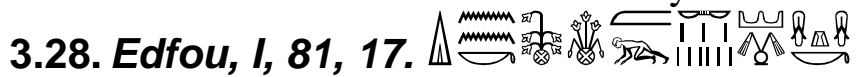

Di.n (.i) $n . k \check{S} m^{\ulcorner} M h w m$ sn-t3, pd dwt psdt dmd $\underline{h} r \underline{t} b t y . k$

"I give to you Upper and Lower Egypt doing obeisance, and the nine Bows united under your sandals".

3.29. Edfou, I, 144, 16.

Di.ỉ n.k Kmt hr mw.k, t3wy-Fnhw r $n d y d$.

"I give to you Egypt loyal to you and the two lands of Phoenicians as slaves".

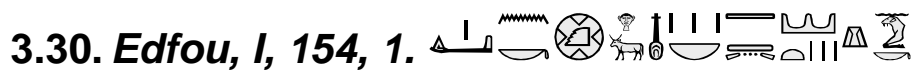

Di.i n.k Kmt hr dwn nfrw nb(w), t3wy ḩsswt hr šfyt.k

"I give to you Egypt offering ${ }^{(\mathrm{e})}$ all good (things), the two lands and foreign lands carrying your terror".

3.31. Edfou, I, 185, 15.

Di.i n.k Kmt hr mw n hm.k, t3wy Sttyw m ndyt.k

"I give to you Egypt loyal to you, the two lands of Asiatic people enslaved for you".

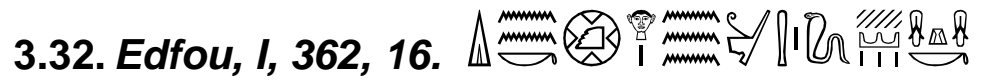

Di.n(.i) n.k Kmt hr mw n hm.k//I// ḩsswt hr thbty.k

"I give to you Egypt loyal to your majesty and the foreign lands are under your sandals".

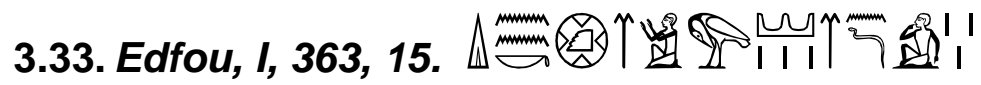

Di.n.i n.k Kmt $m$ ỉsw, Dšrt $m$ ndyt.

"I give to you the Black Land (i.e. Egypt) in praising, the Red Land (desert) enslaved".

3.34. Edfou, I, 375, 1-2.

Di.n(.i) n.k Kmt hr f3i(t) n.k iht.s, h3swt hr in(t) n.k bi3wt.sn

"I give to you Egypt carrying her offerings to you; the foreign lands bringing their wonders to you".

3.35. Edfou, II, 7,3. 1ำ

Nfr.wy hr.k, ỉ.tw m htpnswt n B3kt, Dšrt, Di.ỉ n.k k3wnw Kmt.

"How beautiful is your face, come in peace King of Egypt (the luminous) and Red Land (desert); I give to you provisions of Egypt".

3.36. Edfou, II, 64, 13. 4 =

Di.n(.î) $n . k \check{S} m^{\top} w M h w, p d \underline{d} w p s \underline{d} t \underline{h} r \underline{t b t y} . k$

"I give to you Upper and Lower Egypt, the Nine Bows being under your sandals".

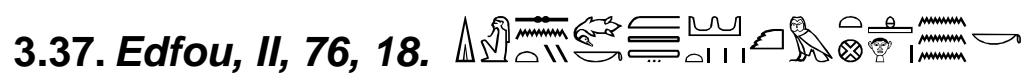

Di.i. sndt.k $m$ T3wy, h3swt, Kmt htp hr mw.k

"I place fear of you in the two lands and foreign lands; Egypt being content and loyal to you".

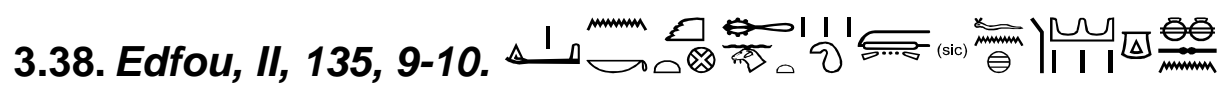

Di.i n.k Kmt $\underline{h} r$ šfyt.k, t3 Fnḩw hr inw.sn

"I give to you Egypt carrying your awe, Land of Phoenicians carrying their tributes". 
3.39. Edfou, III, 133, 16.

\section{Di.i snd.k $m$ t3wy ḩsswt, Kmt htp hr mw.k}

"I place fear of you in the two lands and foreign lands; Egypt being content and loyal to you".

3.40. Edfou, III, 188, 13. Di.i n.k Htmt htm.tw m htm.k

"I give to you Egypt (i.e. the Fortress) closed by your defensive seal".

\subsection{Edfou, IV, 329, 17.}

T3wy hr mw n hm.f, h3swt hri $n$.f $r$ hmw.

"The two lands are loyal to his majesty, and the foreign lands are far from him to be servants".

3.42. Edfou, IV, 341, 12-13.

$D i$ (.i) n.k B3kt b3k.tw $m$ bw nfr, h3swt bdšw w'f `f $3 y . s n^{2}$

"I give to you Egypt luminous with good things; enemies of the foreign lands are subdued in their encampments".

\subsection{Edfou, IV, 341, 17-18. .}

Di.i sndt.k $m$ ḩ3swt nb(w), Kmt htp hr $m w . k$

"I place fear of you in every foreign lands; Egypt is content and loyal to you".

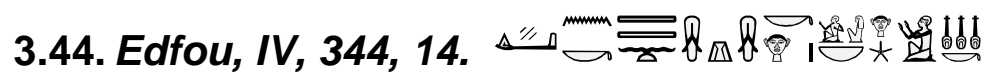

Di (.i) n.k T3wy dmd $\underline{h} r \underline{t b t y . k, ~ h r-n b ~ h r d w 3 n f r w . k}$

"I give to you the two lands united under your sandals, and everyone is praising your beauty".

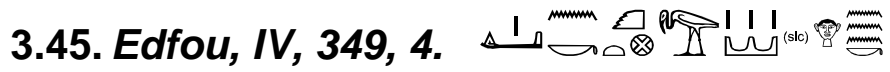

Di.i n.k Kmt, Dšrt hr mw.k

"I give to you Black land (i.e. Egypt) and Red land (i.e. desert) are loyal to you".

3.46. Edfou, IV, 371, 8.

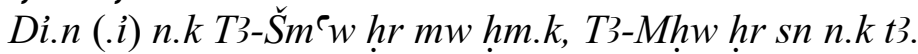

"I give to you Upper Egypt loyal to you, and Lower Egypt kissing for you the land".

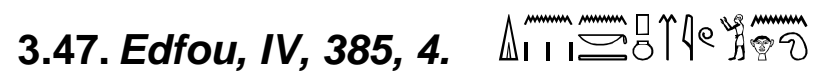

Di.n n.kt3 pn mi3w n hr.k

"We give to you this land in praising for your face".

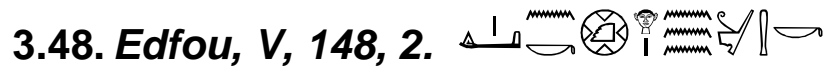

Di.i n.k Kmt hr mw n hm.k

I give to you Egypt loyal to your majesty.

3.49. Edfou, VII, 61, 9.

Di.i n.k Kmt 3h.ti m rk.k

I give to you Egypt effective in your time.

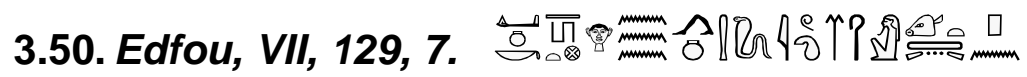

Di.i n.k T3-mry hr mw n hm.k, iw.k $m$ hk $k$ hnt t3 pn.

"I give to you Egypt loyal to your majesty, and you are ruler inside this land".

3.51. Edfou, VII, 153, 6. $-0.81 \%$

$D i(. i) n . k$ t3wy hr mw $n$ hm.k, t3wy nbw dmd $n k 3 . k$

"I give to you the two lands loyal to your majesty, and all the two lands are united for your Ka". 
3.52. Edfou, VII, 186, 16.

Di.i n.k T3-mry hr dw3 n.k ntr.

"I give to you Egypt praising for you the god".

3.53. Edfou, VII, 186, 18.

Di.i n.k B3kt b3k.tw m iht.s

"I give to you Egypt luminous with its offerings".

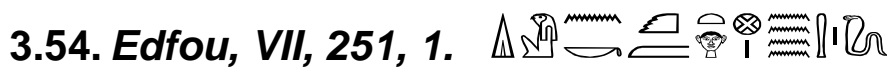

Di.i n.k Kmt hr mw n hm.k

"I give to you Egypt loyal to your majesty.

3.55. Edfou, VII, 303, 7.

$D i(. i) n . k K m t, D s ̌ r t ~[h r m w . k]$.

"I give to you Black land (i.e. Egypt) and Red land (i.e. desert) [loyal to you]". ${ }^{(\mathrm{f})}$

3.56. Edfou, VIII, 33, 14.

Di.i n.k T3-mry $h r d w 3 n . k n t \underline{t} r, h 3 s t y w n b(w)$ sd3 $n$ snd.k

"I give to you Egypt praising for you the god; and all the foreigners are tremble of your fear".

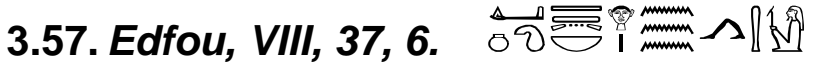

Di.i n.k t3wy nb(w) hr mw hm.k

"I give to you the all the two lands loyal to your majesty".

3.58. Edfou, VIII, 112, 13-14. $\frac{1100000}{00}$

Di.i n.k T3-mry hr hrp n.k iht.sn

"I give to you Egypt consecrate for you her (lit. their) offerings".

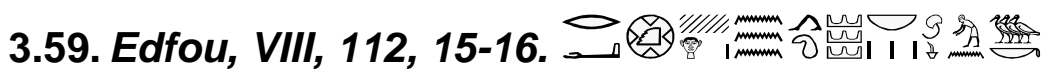

Rdi(.i) Kmt [htp] hr mw.k, h3swt nbw h3b n b3w.k

"I make Egypt [content] and loyal to you, and all the foreign lands are bending of your might".

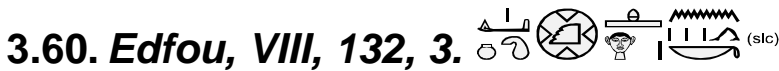

Di.i n.k Kmt htp hr mw.k

"I give to you Egypt content and loyal to you".

3.61. 61- Edfou, VIII, 124, 2.

T3-mry šm $h r m w . k$

"Egypt is loyal to you".

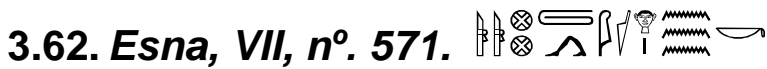

Isty $p h r-m-k d h r m w . k$

"Egypt is rejoice and loyal to you".

3.63. Bénédite, G.; Philae, II, 113, 8.

Di.i n.k Kmt htp hr mw.k

"I give to you Egypt content and loyal to you".

3.64. Bénédite, G.; Philae, II, 113, 9. I

Di.i n.k B3kt hr.tw hr shrw.f

"I give to you Egypt content with her ${ }^{(\mathrm{g})}$ plans". 


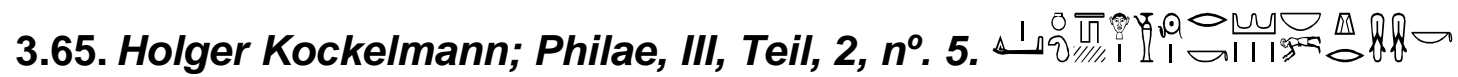
Di.i n.k T3-mry hr hssi $R^{\top} r . k$, ḩ3swt nbw hr hr thbty.k

"I give to you Egypt praising Re for you and all the foreign lands are fallen under your sandals".

3.66. Holger Kockelmann; Philae, III, Teil, $2, n^{\circ} .82$. Di.i n.k T3-mry hr iht nbw.

"I give to you Egypt carrying all offerings".

3.67. De Morgan; Kom Ombos, $I, n^{\circ}$. 287.

Di (.i) n.k Kmt, Dšrt hr iht.sn

"I give to you the Black Land (i.e. Egypt) and the Red Land (i.e. desert) carrying their offerings".

3.68. De Morgan; Kom Ombos, $1, n^{\circ}$. 295. [ 1

[ Di.i $n . k$ ] Kmt htp hr mw.k, Dšrt r ndyt.k

"[I give to you] the Black Land (i.e. Egypt) content and loyal to you and the Red Land (i.e. desert) to become your slaves".

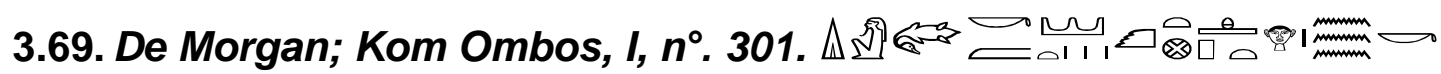
Di.i snd.k $m$ ḩsswt, Kmt htp hr mw.k

"I place fear of you in the foreign lands; Egypt is content and loyal to you".

3.70. Gutbub, Kôm Ombo, I, 184, 2. Di.i n.k inw Kmt m-`b Dšrt.

"I give to you revenue of the Black Land (i.e. Egypt) and the Red Land (i.e. desert)".

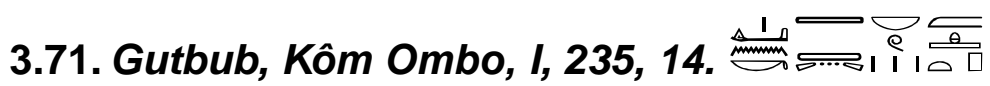
Di.i n.k T3wy nbw $m$ htp.

"I give to you all the two lands in peace".

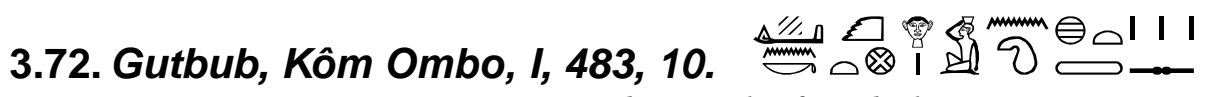

Di.i n.k Kmt hr fii n.k iht.s

"I give to you Egypt carrying to you her offerings".

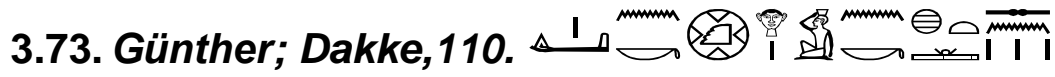

Di.i n.k Kmt hr fỉ n.k iht.sn

"I give to you Egypt carrying to you her (lit.their) offerings".

3.74. Günther; Dakke, 323.

Di.i n.k Kmt htp hr(h) $m w . k$

"I give to you Egypt content and loyal to you".

3.75. Günther; Dakke, 326.

Di.i n.k Kmt htp hr mw.k

"I give to you Egypt content and loyal to you".

3.76. Clère, Porte d'Évergète, 24.

Di.i n.k Kmt hr dw了 n.k, ḩswt n.k r ndyt.

"I give to you Egypt praising for you, foreign lands for you as slaves".

3.77. Aufrère, Propylône d'Amon-Rê-Montou, 42. Di.i n.k t3wy htp hr mw.k

"I give to you the two lands content and loyal to you". 
3.78. Aufrère, Propylône d'Amon-Rê-Montou, 72. Di.n(.i) n.k Kmt hr $n d b^{(\mathrm{i})}$ hr.s, ḩ hswt hr hrp n.k b3k.sn

"I give to you Egypt carrying the whole land with her; foreign lands consecrate to you

3.79. De Wit, Opet, I, 167.

Di.i n.k T3wy nbw ršwt m nfrw.k

"I give to you all the two lands rejoice of your beauty".

3.80. De Wit, Opet, I, 199. 4 I

Di.i n.k T3-mry hr tbtb [13] iht.sn

"I give to you Egypt pulling up her (lit. their) offerings".

3.81. Blackman, the temple of Dendur, P.7. $n^{\circ} . g$.

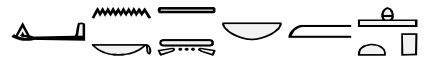

Di (.i) $n . k T 3 w y n b(w) m h t p$.

"I give to you all the two lands in peace".

3.82. Gauthier, H.; Kalabchah,I, P.100.

Di.i n.k T3wy $n b(w) m$ htp.

"I give to you all the two lands in peace".

\section{Egypt of the Gods and Egypt of the King:}

\subsection{Egypt of the gods}

Egypt is under the protection of the gods. The rule of Egypt is one of a number of duties of the gods. The texts emphasize the relationship between gods and Egypt, especially when it is referred to by the word Kmt, as Egypt is the closest place to the heart of gods. It was the best reward that could be given to the King for all that he had done, as the King takes

care of offerings and buildings of the gods. The relationship between the gods and the King was an exchange. The King gives to the gods all that they need and in return, they give him the Kingship of Egypt forever. The relationship clearly appearing in some instances that quote from different temples. One of texts mentioned that:

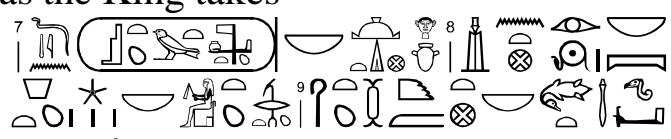

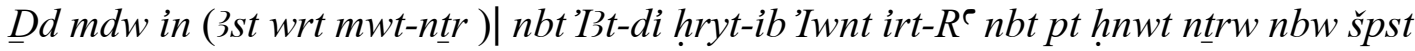
wsrt hk3t n Kmt, nbt sndt, '3t nrw.

"Utterance by (Isis, the great one, the god's mother )| lady of Iount, who resides in

Dendara, Eye of Re, lady of the sky, mistress of all the gods, the noble one, the mighty one, the female ruler of Egypt, lady of fear, great of terror" [14].

4.1.1. In the same text Horus is described as

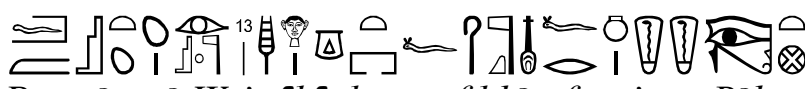

$$
\begin{aligned}
& \text { Pr } m \text { 3st s3 Wsir 'he hr nst.f hk } 3 \text { nfr } n \text { itrty B } 3 k t \text {. }
\end{aligned}
$$

"He who is borne of Isis son of Osiris, who stands upon his throne, the good ruler of the Two Sanctuaries of Egypt" [14].

\subsubsection{Isis in Philae was queen of upper and Lower Egypt:}

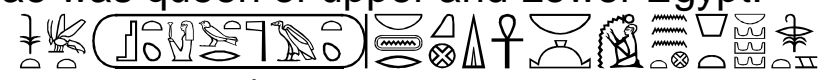

Nswyt-bityt ( 3st wrt mwt-ntr ) $\mid$ nbt'Irk, di ' $n h$, nbt'I3t-w'bt, hnnwt nbt h్ 3swt rsywt. "Queen of Upper and Lower Egypt (Isis, the great one, the god's mother)|, lady of Philae, who gives life, lady of Abaton, the Mistress and Lady of the southern foreign lands" [15]. 


$$
\text { 3t } m \text { pt, wsrt m t3, hnwwt } n \text { Kmt, Dšrt. }
$$

"The great one in the sky, the mighty one in the land, mistress of Egypt, and the red land (i.e. desert)" [5].

4.1.3. Hathor as an avatar of Isis in Philae was

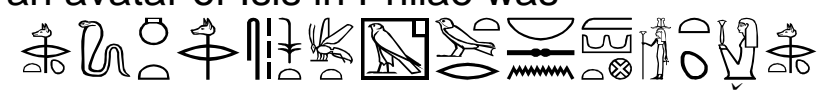

Wsrt nt wsrw, Nswyt-bityt Ht-hr wrt nbt Snmt Spst Wsrt.

"The mighty One of mighty ones, Queen of Upper and Lower Egypt Hathor the great, lady of Biggah, the Noble one, the Mighty one" [14].

\subsubsection{Hathor frequently have the title "Queen of Upper and Lower Egypt" in Dendara}

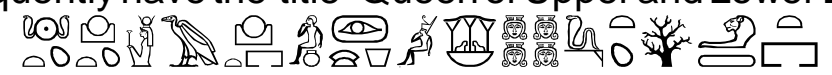

Nswyt-bityt, 3htyt $m$ 3ht, ${ }^{\top} n t h^{\top} w \mathrm{~m}$ fdw hrw, ntrt $m$ ḩ3t.

"Queen of Upper and Lower Egypt, the female horizon-dweller in the horizon, beautiful one of appearance with the four faces, the goddess in the front" [16].

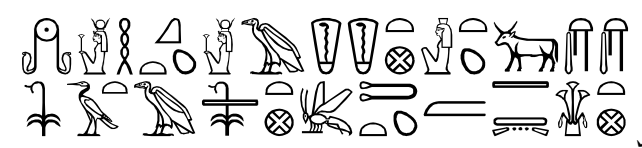

Nswyt-bityt, Ht-hrr hk3t m Itrty, hnwt nbt hpty, nswyt $m$ T3-Š $m^{`} w$ bityt $m$ T3-Mhw. "Queen of Upper and Lower Egypt, Hathor the Female ruler in the Two Sanctuaries, the mistress and lady of universe, Upper queen in Upper Egypt, Lower queen in Lower Egypt" [16].

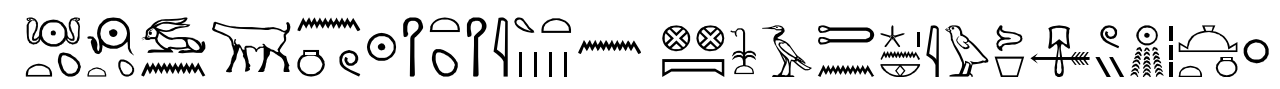

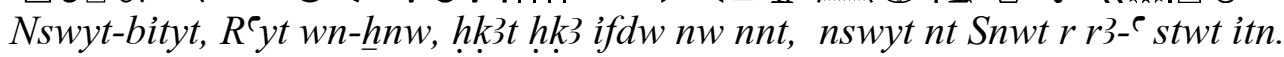

"Queen of Upper and Lower Egypt, Reyt (i.e. female form of Re) who reveals the interior, the Female ruler who rules the four corners of the sky, queen of Egypt to the limit of the rays of the Aten" [16].

\subsubsection{Osiris by his turn was king of upper and lower Egypt}

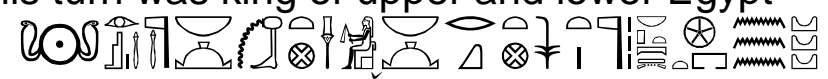

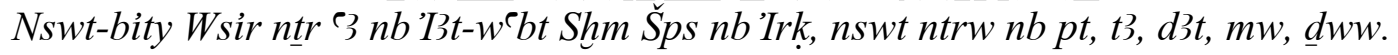
"King of Upper and Lower Egypt, the great god lord of Abaton, the powerful and noble One, lord of Philae, King of gods, lord of heaven, earth, underworld, water and mountains" [15].

- Another text mentioned about Horus Behdety that he is

$$
\text { 马. }
$$

Drty wr phty $n b \check{S} m^{\top} w$ Mhw, S3wty s3w Kmt r dšrwt.

"The falcon great of strength, lord of Upper and Lower Egypt, the protector who protects Egypt from the red lands (i.e. the foreign lands)" [17].

$$
\text { 可 }
$$

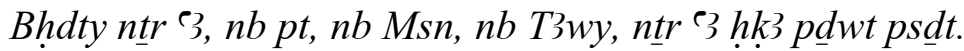

"Behdety the great god, lord of the sky, lord of Mesen (i.e. Edfou); lord of the two

lands, the great god ruler of the Nine Bows" [11].

4.1.6. Horwer by his term described in the texts of Kom Ombo as

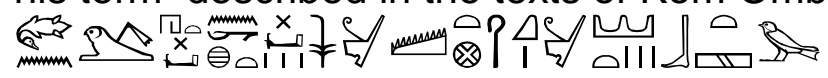

Snd $n$ Hr-wr hd nhtw, nswt n Kmt, hkj 3 ḩswt bdš.

"Fear of Horwer vanquishes the powerful ones, King of Egypt and Ruler of the faint foreign lands" [18]. 


\subsection{Egypt of the king}

As for the King, texts focus on describe him as Horus who controlled and ruled Egypt. In order to giving him

the legitimacy of Kingship. As the King is the heir of Horus on the throne of Egypt.

\section{7ef}

Sw mi Hr iti.n.f T3wy, Šm $w$ Mhw hr mw n hrm.f

"He is like Horus seized the two lands (Egypt); Upper and Lower Egypt are loyal to his majesty" [9].

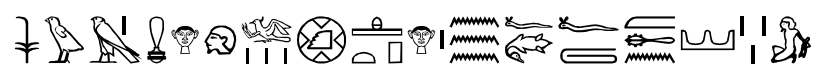

Sw mi Hr hry-tp rhyt Kmt htp hr mw.f, snd.f phr $m$ ht $n$ h̆ $3 s t y w$.

"He is like Horus master of the rhyt-people, Egypt is content and loyal to him, and his fear goes around the body of foreign people" [19].

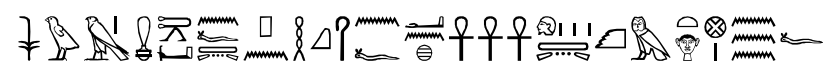

Sw mi Hr iti.n.f t3 pn hkj.n.f 'nhw tpyw t3, Kmt hr mw.f

He is like Horus seized this land and rules livings upon land, Egypt is loyal to him [20].

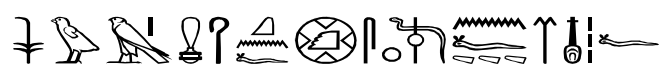

Sw mi Hr hk3.n.f Kmt shd.n.f idbw m nfrw.f

"He is like Horus who ruled Egypt, who illumines the banks with his beauty" [20].

$$
\begin{aligned}
& \text { 7ef } \\
& \text { Sw mi Hritín.f B3kt ity.n.f t3wy nbw. }
\end{aligned}
$$

"He is like Horus seized Egypt, who ruled all the two lands" [21].

On the other hand, the texts also describe the King as Ruler and lord of

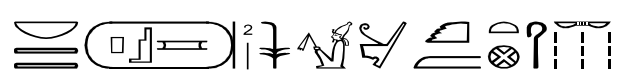

Nb-t3wy ( Ptwlmys mry 3st )| nswt n Kmt hlk 3 pdwt ps $\underline{d} t$.

"Lord of the two lands (Ptolemy Beloved of Isis)|, King of Egypt and ruler of the nine Bows" [5].

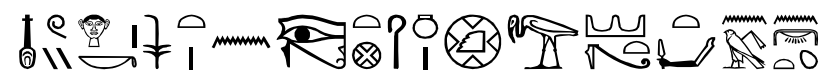

Nfr.wy hr.knswt n B3kt, hkj n Kmt Dšrt, tit dsrt n Bik-n-Nbwt.

"How beautiful is your face king of Egypt, ruler of the Black Land (i.e. Egypt) and the Red land (i.e. desert), the sacred image of the Falcon of the Golden One" [12].

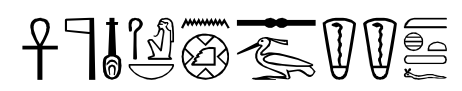

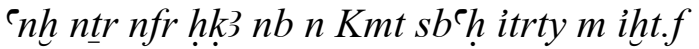

"May the good god live, the ruler and lord of Egypt, who floods the Two Sanctuaries with his offerings" [22].

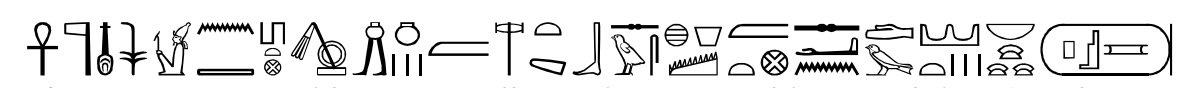

'nh ntr nfr nswt n T3-mry, hbi inw m ndb, swsh Kmt, s'nd ḩ3swt, nb h̆'w (Ptwlmys mry 3st )|. "May the good god live, King of Egypt, who gathering tributes from the whole land, who make wide Egypt and make small foreign lands, lord of the diadems (Ptolemy

$$
\text { Beloved of Isis)|" [5]. }
$$

- In parallel text the King also was

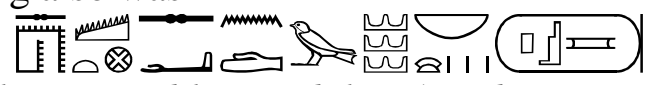

šwsh Kmt s`nd ḩswt nb h`w (Ptwlmys mry 3st)|.

"He makes wide Egypt and makes small foreign lands, lord of the diadems (Ptolemy Beloved of Isis)|" [5]. 


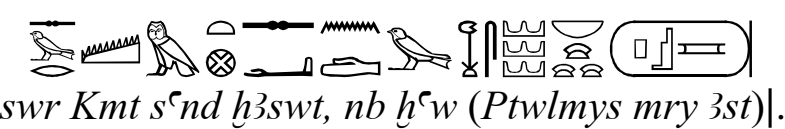

"Who make great Egypt and make small foreign lands, lord of the diadems (Ptolemy Beloved of Isis)|" [5].

- Another text mentioned the relation between Egypt and the King $\square$ -

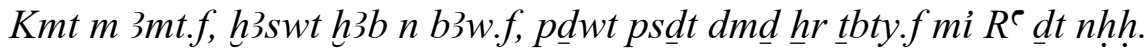

"Egypt is in his fist, the foreign lands are bending of his might, the Nine Bows united under his sandals, like Re forever and eternally" [23].

- In other texts the King was the Nile of Egypt

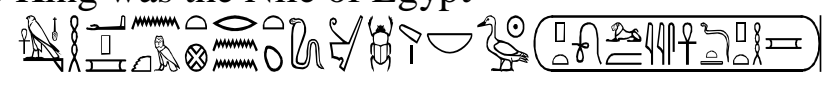

‘nh ntr nfr H'py n Kmt, Rnnt n $t 3$ nbt, s3-Re (Ptwlyms 'nh dt mry-Pth )|. "May the good god live, the Nile of Egypt, Rennent of all the land, son of Re,

(Ptolemy, living forever, beloved of Ptah)|" [12].

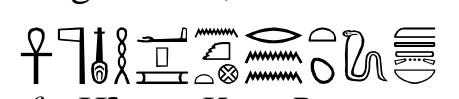

'nh ntr nfr, H'py n Kmt, Rnnt m t3wy nbw.

"May the good god live, the Nile of Egypt, Rennent in all the two lands" [22].

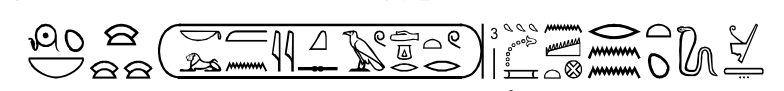

$S 3-R^{\complement} n b-h^{\top} w$ (Grmnyks, 3wtwkrtwr )| H'py n Kmt, Rnnt $n$ t3.

"Son of Re, lord of diadems (Germanicus, Autocrator )|, the Nile of Egypt, Rennent of the land" [24].

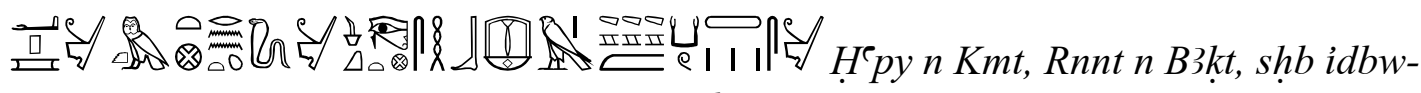 $\mathrm{Hr} m \mathrm{k}$ k3w.sn}

"The Nile of Egypt, Rennent of Egypt (i.e. the luminous), who make festive the banks of Horus with its offerings" [20].

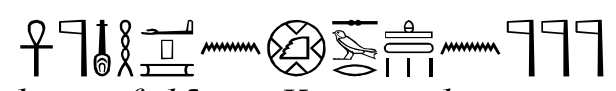

'nh ntr nfr he py $n$ Kmt, swr htpw n ntrw.

"May the good god live, the Nile of Egypt, who makes great (spreads) the offerings for the gods" [25].

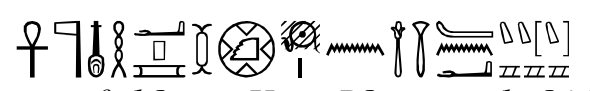

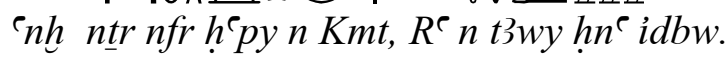

"May the good god live, the Nile of Egypt, Re of the two lands and land plots" [26].

- The texts also describe the King as

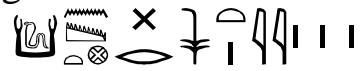

$$
\begin{aligned}
& \text { K3 } n \text { Kmt wr nswyt. }
\end{aligned}
$$

"The Ka of Egypt and great of Kingship" [9].

- Available text addressed the King as the destiny of Egypt and Ka of whom inside it. As it mentioned

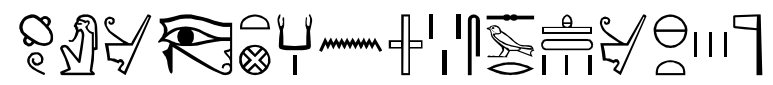

$\check{s} 3 w$ [3] $n$ B3kt k3 $n$ imyw.s swr htpw $n$ ps $\underline{d} t$.

"The destiny of Egypt, Ka of those whom inside it, who makes great (spreads) offerings of the Ennead" [25].

- The texts describe the King as the one chosen by the god to rule Egypt: 


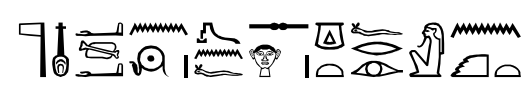

Ntr nfr iw` $n R^{\top}$ stp.n.f sw hr nst.f $r$ irt nswt $n$ Kmt.

"The good god, heir of Re, whom he has chosen to be upon his throne to act as the

King of Egypt" [27].

- The texts consider Alexander the great as the guardian of Egypt:

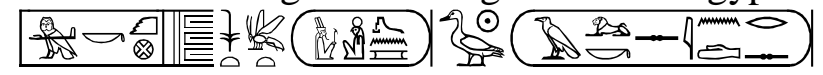

Mk Kmt, Nswt -bity (Mry-R`, Stp-n-Imn)| S3-R` (3lksindrs )|

"The Guardian of Egypt, king of Upper and Lower Egypt (Beloved of Re, Chosen of Amon)| Son of Re (Alexandrs)|" [28-30].

Egypt was giving as a reward by the deified ancestor kings to the ruler king. At

Edfou Ptolemy III and Berenike decalres to their son Ptolemy IV

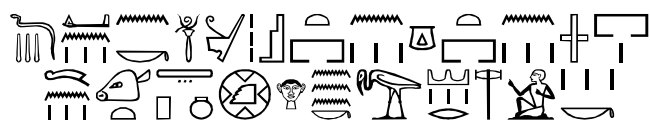

Dd mdw, di.n n.k i3t.n, st.n, nst.n, imyt-pr.n hnt T3-pn, Kmt hr mw.k, Dšrt r ndyt.k "Utterance, we give to you our office, our place, our throne, our testament inside this land, Egypt is loyal to you, the Red Land to become your slaves" [5].

- The texts of Roman emperors united between seize Egypt and rule of Rome

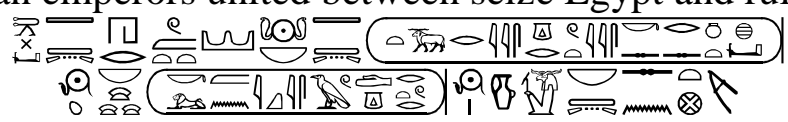

iti T3wy Hrm ${ }^{(\mathrm{j})}$ nswt-bity nb-t3wy (Tbrys, Krwtys, Ksrs, nty-hw)| S3-R $R^{\mathrm{c}} n b-h^{\mathrm{c}} w$

(Grmnyks, 3wtkrtwr)| mry Hnm-R ${ }^{\top} n b$ T3-snt di ${ }^{\top} n h$ mi $R^{\top} \underline{d}$ t.

"He who seize the two lands (i.e. Egypt) and Rome, King of upper and lower Egypt, lord of the two lands (Tiberius, Claudius, Caesar, Sebastos $\left.{ }^{(\mathrm{k})}\right) \mid$; Son of Re and lord of diadems (Germanicus, Autocrator)|, Beloved of Khunm-Re lord of Esna" [28].

\section{Conclusion}

The Ptolemaic texts use a number of synonyms words for "reward". The relation between the King and the gods represents the idea of an exchange. The King as provider gives offerings to the gods as recipients. They reward him with Egypt itself as Kmt and its synonyms. The texts emphasize giving the king Egypt in loyal to him, as he can ruled Egypt in peace. A number of synonyms are used for Egypt such as (Isty, B3kt, Snwt, T3, T3wy, T3-mry, T3-ŠSm 'w, T3-Mhw). Egypt belongs to both the gods and the king. Egypt was given to the king not only by gods but also by his deified ancestor kings. The most frequently word used for Egypt as a reward in texts was Kmt. The King is the legitimate intermediary between the human and divine worlds, his ritual actions and performative words have power and authority. And whatever the offering that was presented by the king, the best reward for his act was Egypt itself. The texts make the foreign lands utterly vanquish by the king in parallel with the loyal Egypt. In metaphoric expression all the foreign lands was under the king's sandals. And all the foreign peoples were his slaves. According to the documents were examined the king was: the powerful, the Nile, the ka, the destiny, the guardian of Egypt, who make wide Egypt and make small foreign lands. The texts of Roman emperors compare between the control of Egypt and rule of Rome. As Egypt was the avatar of Rome in the entire Roman Empire. The texts deal with Egypt in three cases as singular masculine, singular feminine and also common plural. Egypt was the top and master reward for the king. That reflexes the deep relation between the gods and the kings. In brief, Egypt was the core of all offerings that the king presented.

\section{Endnotes}

(a) This sign can also written astit;

(b) The scribe confused with the pronoun of the queen Cleopatra VII. He uses the suffix pronoun singular feminine $\infty$.t at the beginning of the sentence, and it uses the suffix pronoun singular masculine ${ }^{\vartheta} . k$ at the end. The scribe 
confused the queen and the King. Cauville in her publication of Dendara XII texts did not mentioned the pronoun ${ }^{2}$ as being incorrect (sic) [14].

(c) Cauville read 8 as $T 3-m r y$ in her translation of Dendara XV. [32] the sign is a combination of the sign read as $t 3$ and $\mathrm{mead}$ as mry [31]. Gutbub read the word $\mathrm{n}$ 는 mean desert [33].

(d) The sign (I20) is read as Kmt and represents an ideogram for the name of Egypt [34]. Fairman notes that here the sign which gives a part of spelling is placed within the determinative [35].

(e) The sign (E1) is read as $d w n$ [3136], the origin meaning of the verb is "to stretch out" $[3,8]$; $d w n$ can also have the meaning "to offer" or "to present" $[3,8]$.

(f) For the possible restoration of the lacuna, compare with Document $n^{\circ} .45$.

(g) The scribe confused the suffix pronouns used to refer to Egypt and its synonyms. He deals refer to Egypt by three suffix pronouns:

1- Singular masculine f $f$ doc. $\mathrm{n}^{\mathrm{o}}$. $19 ; 64]$,

\section{References}

[1] Cauville, S., (2012). Offerings to the gods in Egyptian temples, Peeters press, Leuven.

[2] Asa, G., (1992). The meaning of KMT (Ancient Egyptian) history for contemporary African American experience, Phylon, Vol. 49, (1/2), pp: 10-22.

[3] Wilson, P., (1997). A Ptolemaic Lexikon. A Lexicographical study of the texts in the temple of Edfu, OLA, Vol. 78, Peeters Publisher \& Department of Oriental Studies, Belgium.

[4] Chassinat, É. \& Daumas, F., (1972). Le temple de Dendara, Tome VII, Institut français d'archéologie orientale, Le Caire.

[5] Chassinat, É., (1892). Le Temple d'Edfou, Tome I, Institut français d'archéologie orientale, Le Caire.
2- Singular feminine $\rightarrow . s$ [doc. $\mathrm{n}^{\mathrm{o}} .5$; 34; 53; 72], \& 1- 3- Common plural 11। sn [doc. $\mathrm{n}^{\mathrm{o}} .58 ; 73$ ].

(h) Günther notes that $\{$ read as Hr [37] this is a specific writing that appears in the temple of Dakke. It is equal to the preposition $\mathrm{Hr}$. This reading is derived from a comparison of a two sentences that appears both at Dakke and at Philae:

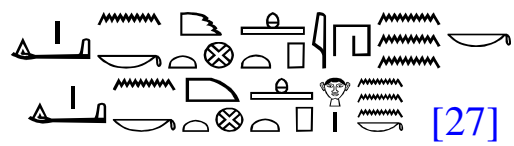

Di.i n.k Kmt htp hr mw.k

Means "I give to you the two lands content and loyal to you". The reading is clear and indicates that $Q \square$ is read as $h r$.

(i) The word $n d b$ 中(Aa27D) refers to the whole land [8]. Wilson notes that $n d b$ is a synonym of $t 3$ in exactly analogous ways [3].

(j) For Hrm as Rome see [38].

(k) For the translation of the title $n t y-h w$ as "Sebastos" see [39].

[6] Chassinat, É., (1929). Le Temple d'Edfou, Tome IV, Institut français d'archéologie orientale, Le Caire.

[7] Chassinat, É., (1939). Le mammisi d'Edfou, MIFAO, Vol. 16, Institut français d'archéologie orientale, Le Caire.

[8] Erman, A. \& Grapow, H., (1957). Wörterbuch der Ägyptischen sprache, 7 Bde, J. C. Hinrichs' Sche Buchhandeung, Leipzig.

[9] Chassinat, É. \& Daumas, F., (1935). Le temple de Dendara, Tome III, Institut français d'archéologie orientale, Le Caire.

[10] Chassinat, É., (1928). Le temple d'Edfou, Tome III, Institut français d'archéologie orientale, Le Caire.

[11] Chassinat, É., (1931). Le temple d'Edfou, Tome VI, Institut français d'archéologie orientale, Le Caire. 
[12] Chassinat, É., (1918). Le temple d'Edfou, Tome II, Institut français d'archéologie orientale, Le Caire.

[13] Hannig, R., (2006). Die sprache der pharaonen: Großes Handwörte-rbuch Ägyptisch-Deutsch, Band 1 (Kulturgeschichte der antiken Welt. Band 64) 4. Auflage, von Zabern, Mainz.

[14] Cauville, S., (2007). Dendara, XII, Institut français d'archéologie orientale, Le Caire.

[15] Kockelmann, H. \& Winter, E., (2016). Die zweite ostkolonade des tempels der Isis in Philae (CO II und CO II K) Reihe: Denkschriften der Gesamtakademie-Sonderbände, Band: 78, Verlag der Österreichischen Akademie der Wissenschaften, Öste-rreich.

[16] Cauville, S., (2007). Dendara, XIII, www.dendara.net, 14/10/2015

[17] Kurth, D., (2014). Die inschriften des tempels von Edfu. Abteilung I Übersetzungen; Band 3. Edfou VI, PeWeVerlag, Gladbeck.

[18] De Morgan, J., Bouriant, U, Legrain, G., Jéquier, G. \& Barsanti, A., (1895). Catalogue des monuments et inscriptions de l'Égypte antique. Première série: Haute-Egypte, Tome second: Kom Ombos, Première partie, Adolphe Holtzhausen, Vienne.

[19] Clère, J., (1961). La porte d'évergète à Karnak, MIFAO, Vol. 84, Institut français d'archéologie orientale, Le Caire.

[20] Aufrère, S., (2000). Le propy-lône d'Amon-Rê-Montou à Karnak-nord, MIFAO, Vol. 117, Institut français d'archéologie orientale, Le Caire.

[21] Chassinat, É., (1932). Le temple d'Edfou, Tome VII, Institut français d'archéologie orientale, Le Caire.

[22] De Wit C., (1958-1962). Les inscriptions du temple d'Opet, à Karnak 12, Bibliotheca Aegyptiaca, Vols. 1112, Bruxelles.

[23] Sethe, K., (1904). Urkunden der Griechisch-Römischen zeit, II, J. C. Hinrichs'Sche Buchhandeung, Leipzig.

[24] Sauneron, S., (1963). Esna, II, Institut français d'archéologie orientale, Le Caire.

[25] Sethe, K., (1957). Thebanische tempelinschriften aus griechisch-römischer Zeit, Bande I, Akademie-Verlag, Berlin.
[26] Zivie-Coche, C. (1982-1986). Le temple de Deir Chelouit, Tome I-IV, Institut français d'archéologie orientale, Le Caire.

[27] Bénédite, G., (1895). Le temple de Philoe, Tome I-II, MMAF, Vol. 13, fasc.1-2, Leroux, Paris.

[28] Bosch-Puche,F., (2013).TheEgyptian royal titulary of Alexander, JEA, Vol. 99, pp: 131-154.

[29] Bosch-Puche,F.,(2014). TheEgyptian royal titulary of Alexander, JEA, Vol. 100, pp: 89-109.

[30] Beckerath, J., (1984). Handbuch der Ägyptischen königsnamen, MÄS, Vol. 49, Deutscher Kunstverlag, München-Berlin,

[31] Daumas, F., (1995). Valeurs phonétiques des signes hiéroglyphiques d'époque gréco-romaine, Orientalia Monspeliensia IV, Publications de la Recherche, Montpellier.

[32] Cauville, S., (2012). Dendara, XV, Traduction, OLA Vol. 213, Peeters Pub. \& Department of Oriental Studies, Leuven, Belgium.

[33] Gutbub, A., (1952). Le inscriptions dédicatoire des trésor dans le temple d'Edfou, BIFAO, Vol. 50, pp : 33-48.

[34] Kurth, D., (2007). Einführung ins Ptolemäische, Band, I, eine Grammatik mit Zeichenliste und Übungsstücken, Backe-Verlag, Hützel.

[35] Fairman, H., (1954). An introduction to the study of Ptolemaic signs and their values, BIFAO, Vol.43, pp.51-138.

[36] Leitz, Chr., (2004). Quellentexte zur ägyptischen religion I., Lit Verlag, Münster.

[37] Günther, M., (1930). Der tempel von Dakke, les temples imm-ergés de la Nubie, Institut français d'archéologie orientale, Le Caire.

[38] De Wit C., (1961). Une mention de Rome dans un texte hiéroglyphique du temps d'Auguste; in: Mélanges Mariette, BdE, Vol. 32, 1961, pp: 63-69 ; note. (j)

[39] Leitz, Chr., (2010). Der lobpreis des krokodils: Drei sobekhymnen aus Kom Ombos, OLA, Vol. 194, Peeters Publisher \& Department of Oriental Studies, Leuven, Belgium, pp: 291-355. 